\title{
PENINGKATAN KAPASITAS PRODUKSI BUDIDAYA LELE PADA KOLAM BIOFLOC BERTENAGA SURYA UNTUK KETAHANAN PANGAN DI MASA PANDEMI COVID 19
}

\author{
Nurhadi $^{*}$, Chandra Wiharya ${ }^{2}$, Lisa Agustriyana ${ }^{3}$ \\ ${ }^{1}$ Jurusan Teknik Mesin/Program Studi Teknik Otomotif Elektronik, Politeknik Negeri Malang \\ ${ }^{2}$ Jurusan Teknik Elektro/Program Studi Teknik Listrik, Politeknik Negeri Malang \\ ${ }^{3}$ Jurusan Jurusan Teknik Mesin/Program Studi Teknik Mesin, Politeknik Negeri Malang \\ *Email Korespondensi: nurhadiabuzaka@gmail.com
}

Submitted : 8 September 2021; Revision : 13 September 2021; Accepted : 3 Oktober 2021

\begin{abstract}
ABSTRAK
Pandemi Covid-19 berdampak pada melemahnya kemampuan ekonomi masyarakat yang tergabung dalam Poklahsar Citara Singosari Malang yang mengembangkan budidaya ikan lele pada kolam biofloc. Masalahnya, kemampuan ekonomi yang rendah menyebabkan mereka hanya mampu mengembangkan 4 unit kolam, sehingga hasilnya belum optimal. Untuk mengatasinya, dilakukan kegiatan pengabdian masyarakat ini. Metode pengabdian adalah metode difusi Ipteks untuk menghasilkan kolam biofloc bertenaga surya. Tahapan kegiatan meliputi: menyiapkan lokasi, mendesain, membuat dan memasang kolam biofloc bertenaga surya. Karya utama berupa 4 unit kolam biofloc bertenaga surya, berdiameter @ 2 m dengan kapasitas 3.000 ekor ikan/kolam. Pompa air kolam digerakkan oleh panel surya berkapasitas 500 WP dan mampu menyala 24 jam/hari. Dampak dan manfaat yaitu terjadi pemberdayaan masyarakat dan lingkungan yang cukup signifikan. Masyarakat mampu mengubah lahan kosong yang tidak produktif menjadi lahan produktif untuk pengembangan budidaya lele biofloc. Jumlah kolam yang semula hanya 4 unit dan berukuran kecil, diameter@1,5 m, berkembang menjadi 10 unit berukuran besar, diameter@2-4 m, yang semuanya digerakkan oleh pompa air bertenaga surya, sehingga kebutuhan listrik menjadi zero (nol). Perhitungan kapasitas produksi dan omzet budidaya lele naik mencapai 4 kali lipat dari sebelumnya. Kolam biofloc bertenaga surya ini sangat penting untuk meningkatkan kapasitas produksi budidaya lele dan ketahanan pangan masyarakat di masa pandemi, sehingga potensial dikembangkan lagi di kemudian hari.
\end{abstract}

Kata kunci : Budidaya Lele, Kolam Biofloc, Panel Surya, Ketahanan Pangan, Covid-19

\section{ABSTRACT}

The Covid-19 pandemic has had an impact on the weakening of the economic capacity of the people who are members of Poklahsar Citara Singosari Malang, which develops catfish farming in bio floc ponds. The problem is, their low economic capacity causes them to only be able to develop 4 pool units, so the results are not optimal. To overcome this, this community service activity was carried out. The dedication method is a science and technology diffusion method to produce solarpowered bio floc ponds. The activity stages include: preparing the site, designing, constructing, and installing a solar-powered bio floc pond. The main work is 4 units of solar-powered bio floc ponds, diameter@2 m with a capacity of 3,000 fish/pond. The pool water pump is driven by solar panels with a capacity of $500 \mathrm{WP}$ and is capable of running 24 hours/day. The impacts and benefits are significant community and environmental empowerment. The community can convert unproductive vacant land into productive land for the development of bio floc catfish cultivation. The number of pools thatwere 4 units,diameter@1.5 m, has grown to10 units, diameter@2-4 m, all of which are driven by solar-powered water pumps, so the electricity demand becomes zero. Calculation of production capacity and turnover of catfish cultivation increased 4 times from the previous. This solar-powered bio floc pond is very important to increase the production capacity of catfish cultivation and community food security during the pandemic, so it has the potential to be developed again in the future.

Keywords: Catfish Cultivation, Biofloc Ponds, Solar Panels, Food Security, Covid-19 


\section{PENDAHULUAN}

Merebaknya wabah virus corona berdampak pada berbagai sektor kehidupan. Penyebaran penyakit ini telah memberikan dampak luas secara sosial dan ekonomi (Susilo et al., 2020). Penyakit virus corona 2019 (corona virus disease/Covid-19) adalah nama baru yang diberikan oleh Wolrd Health Organization (WHO) bagi pasien dengan infeksi virus novel corona 2019 yang pertama kali dilaporkan dari kota Wuhan, Cina pada akhir 2019 (Handayani, Hadi, Isbaniah, Burhan, \& Agustin, 2020).

Sektor yang terdampak Covid -19 tak terkecuali adalah sektor Usaha Mikro Kecil dan Menengah (UMKM). Padahal UMKM memiliki peran yang sangat strategis dalam perekonomian Indonesia. Data Kementerian Koperasi dan Usaha Kecil dan Menengah Indonesia tahun 2018 menunjukkan jumlah unit usaha UMKM 99,9\% dari total unit usaha atau 62,9 juta unit. UMKM menyerap $97 \%$ dari total penyerapan tenaga kerja, $89 \%$ di antaranya ada di sektor mikro, dan menyumbang $60 \%$ terhadap produk domestik bruto (Bahtiar \& Saragih, 2020).

Diantara masyarakat yang terdampak pandemic Covid-19, salah satunya adalah melemahnya kemampuan ekonomi masyarakat RT 02 RW 13 Desa Banjaarum Kec. Singosari Kabupaten Malang. Hal itu mendorong masyararakat membuat terobosan baru untuk menjamin ketahanan pangan dan tetap ada sumber penghasilan, yaitu dengan mengembangkan budidaya ikan lele biofloc (biofloc dan hidroponik) yang dimotori oleh Bapak Wahyu dari UKM Citara. Wahyu (2020) mengatakan bahwa budidaya ikan lele sistem biofloc merupakan penggabungan antara sistem biofloc dan hidroponik (Utomo, 2020). Budidaya ikan lele sistem biofloc dilakukan dengan menumbuhkan mikroorganisme yang berfungsi mengolah limbah budidaya itu sendiri menjadi gumpalan-gumpalan kecil (floc) yang justru bermanfaat sebagai makanan alami ikan. Teknologi biofloc atau lumpur aktif merupakan adopsi dari teknologi pengolahan biologis air limbah lumpur aktif dengan menggunakan aktivitas mikroorganisme untuk meningkatkan karbon dan nitrogen (Faridah, Diana, \& Yuniati, 2019). Budidaya ikan lele sistem biofloc tidak diperlukan lahan kolam yang luas, cukup kolam buatan menggunakan bahan terpal dengan rangka bambu atau besi, namun diperlukan pemasok sirkulasi oksigen dari dalam kolam, misalnya menggunakan aerator atau pompa air (Manggala P Putra, 2015). Hidroponik merupakan konsep budidaya tanaman yang memanfaatkan air tanpa membutuhkan tanah untuk media tanam. Pada hidroponik mementingkan pemenuhan nutrisi tanaman, agar tanaman dapat hidup dan tumbuh (Murniaseh, 2020). Sedangkan hidroponik adalah inovasi dalam budidaya tanaman tanpa media tanah namum memanfaatkan nutrisi, air, serta bahan yang porus sebagai media tanam (Kamalia, Dewanti, \& Soedradjad, 2017). Hidroponik adalah cara bercocok tanam alternatif di perkotaan. Mudah, terkendali, dan bisa dilakukan di media tanpa tanah, bahkan di dalam rumah (Rakhman, 2015). Kolam biofloc dan suasana panen lele UKM Citara sebagaimana Gambar 1-3.

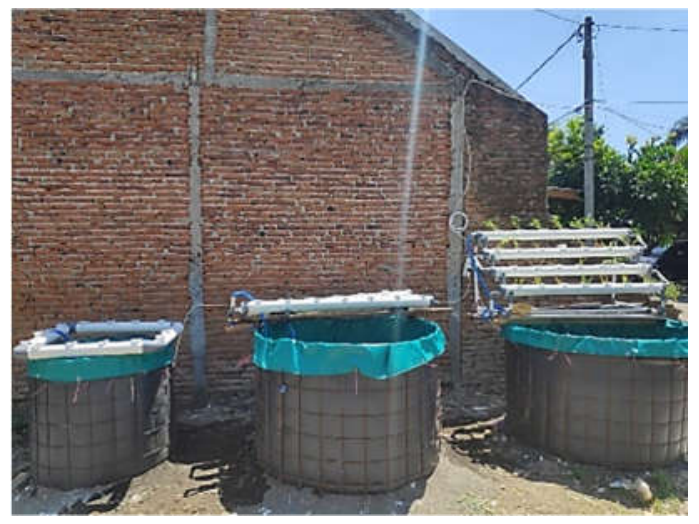

Gambar 1. Kolam Ikan Lele Biofloc 


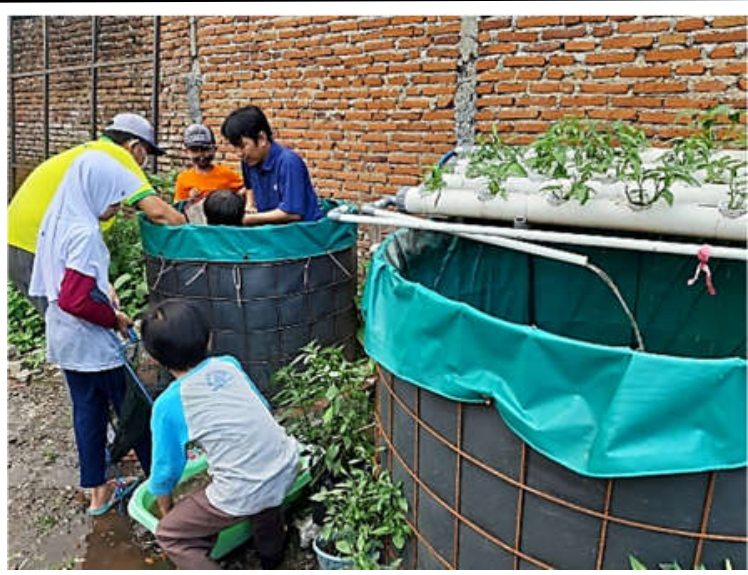

Gambar 2. Persiapan Panen Lele Biofloc

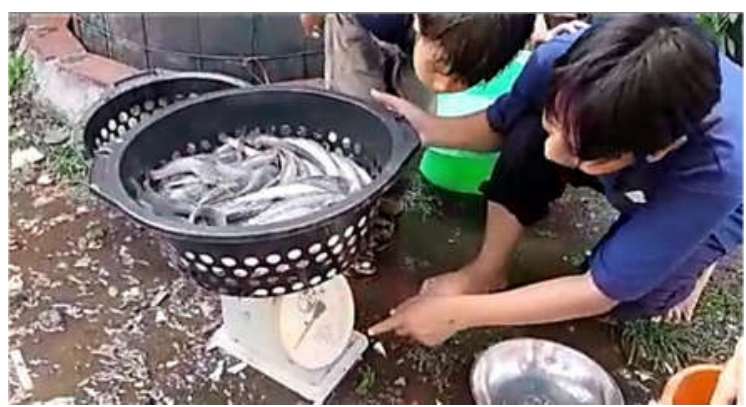

Gambar 3. Penimbangan Hasil Panen Lele Biofloc

Gambar 1-3 menunjukkan bahwa usaha budidaya ikan lele pada kolam biofloc yang dilakukan masyarakat RT 02 RW 13 Desa Banjaarum Kec. Singosari Kabupaten Malang dibawah koordinasi Poklahsar Citara sudah berjalan, namun masalahnya, walaupun masyarakat telah mengembangkan budidaya ikan lele biofloc, akan tetapi kemampuan ekonomi yang rendah karena terdampak pandemi Covid-19, menyebabkan masyarakat hanya mampu mengembangkan 4 unit kolam, sehingga hasilnya belum optimal. Kolam biofloc tersebut juga butuh pompa air yang bekerja 24 jam, namun UKM tidak memiliki sumber energi listrik alternatif sebagai penggerak pompa air sebagai penunjang proses budidaya ikan lele, dan biaya listrik PLN yang tinggi (Anonimous, 2020), sehingga membebani UKM. Rata-rata biaya listrik untuk 4 kolam lele selama 1 periode panen (3 bulan) adalah Rp. 1.200.000,-. Jumlah kolam ikan lele biofloc yang dimiliki Poklahasar Citara sebanyak 4 unit kolam @ diameter 1,5 m. Omzet setiap panen (3 bulan) rata-rata Rp. 6.400.000,- Namun setelah dikurangi biaya pakan, keuantungan tinggal rata-rata $\mathrm{Rp}$ $1.360 .000,-$. padahal biaya listrik Rp 1.200.000,-. Sehingga dapat dikatakan usahanya masih impas, belum ada keuntungan. Untuk mengatasi permasalahan tersebut, dilakukan kegiatan pengabdian masyarakat berupa pemasangan 4 unit kolam biofloc bertenaga surya ini dengan tujuan agar dicapai peningkatan kapasitas produksi dan keuntungan untuk menjamin ketahanan pangan di masa pandemi COVID-19.

\section{METODE}

Metode pengabdian adalah metode difusi Ipteks, yaitu gabungan ilmu teknik mesin dan elektro untuk menghasilkan produk berupa kolam biofloc bertenaga surya. Tahapan kegiatan meliputi: menyiapkan lokasi, mendesain, membuat dan memasang kolam biofloc bertenaga surya. Kolam dipasang di lahan kosong (lahan tak produktif) seluas kurang lebih 
$2.000 \mathrm{~m}^{2}$ yang terletak di pinggir sungai, sedangkan panel surya diletakkan diatas genteng yang terpapar sinar matahari langsung. Komponen kontroller, baterai, saklar, dll ditempatkan pada tempat yang aman, bebas dari panas dan hujan. Peningkatan kapasitas produksi budidaya lele biofloc dilakukan dengan menghitung dan membandingkan hasil rata-rata budidaya ikan lele selama 1 kali panen ( 3 bulan), ketika sebelum dilakukan kegiatan pengabdian (budidaya pada 4 unit kolam) dan setelah dilakukan kegiatan pengabdian (budidaya pada 10 unit kolam). Subjek yang dihitung dan dibandingkan yaitu kapasitas ikan lele yang dibudidayakan, nilai omzet yang diperoleh, dan biaya listrik. Tahapan proses monitoring dan evaluasi terhadap pelaksanaan program pengabdian masyarakat ini dilakukan pada 4 point berikut, yaitu: 1) menguji coba fungsi kolam biofloc, 2) menguji coba sistem tenaga surya sebagai penggerak pompa kolam biofloc, 3) menghitung peningkatan kapasitas produksi budidaya ikan lele, dan 4) melihat dampak perubahan sosial yang ditimbulkan. Uji coba fungsi kolam biofloc dilakukan dengan mengetes ada tidaknya kebocoran air kolam. Uji coba sistem tenaga surya sebagai penggerak pompa kolam biofloc dilakuan dengan menghitung kemampuan sel surya dalam menghasilkan energi listrik untuk menggerakkan pompa. Peningkatan kapasitas produksi budidaya ikan lele dihitung kapasitasnya sebelum dan sesudah kegiatan. Dampak perubahan sosial yang ditimbulkan dilihat secara langsung perubahan yang terjadi sebelum dan sesudah kegiatan.

\section{Pembuatan Jadwal}

Jadwal kegiatan pengabdian dibuat dalam kurun waktu 8 bulan, mulai tahap awal kegiatan hingga selesai. Tahapan kegiatan meliputi: menyiapkan lokasi, mendesain, membuat dan memasang kolam biofloc, mendesain dan memasang sistem tenaga surya penggerak pompa kolam biofloc, menebar benih ikan lele dan membesarkannya sampai menjelang panen, serta menyerahterimakan alat hibah Pengabdian Pada Masyarakat (PPM) kepada mitra.

\section{Pembuatan desain dan penentuan material}

Desain kolam biofloc dan instalasi tenaga surya dibuat menggunakan software corel draw. Material kolam dipilih dari bahan kolam biofloc yang umum di pasaran, yaitu ramraman besi untuk rangka kolam dan terpal khusus kolam untuk dindingnya. saluran pembuangan air kolam menggunakan pipa PVC diameter 3 inchi. Material panel surya dipilih jenis monocrystalin 100 WP sebanyak 5 unit. Kontroller dipilih jenis hybrida 850 VA, dan baterai dipilih jenis VRLA $200 \mathrm{AH}$.

\section{HASIL DAN PEMBAHASAN}

Karya utama kegiatan PPM ini ada 2, yaitu:

1. Satu set Pembangkit Listrik Tenaga Surya (PLTS), dengan spesifikasi:

Kapasitas Panel Solar Cell : 500 WP

Kapasitas Baterai $\quad: \quad 200 \mathrm{AH}$

Kapasitas Controller Hybrid $\quad$ : 850 VA

Kapasitas Keluaran Baterai Maksimum $\quad: \quad 160 \mathrm{AH}$

2. Empat Unit Kolam Biofloc, dengan spesifikasi:

Diameter kolam : 2 meter (masing-masing kolam)

Kapasitas kolam : $\quad 3.000$ ekor lele tiap kolam

Perlengkapan kolam : 12.000 Bibit lele ukuran 5-7 cm, pakan 1 x panen

Alat PLTS untuk Poklahsar Citara Desa Banjararum Kec. Singosari Kabupaten Malang selaku mitra PPM terdiri dari 5 unit panel surya @ 100 WP (400 WP), 1 unit controller hybrid 850 VA, 1 unit baterai VRLA 200 AH, 2 unit lampu@14 watt, saklar $\mathrm{MCB}$, voltmeter, amperemeter dan kabel. Kemampuan pembangkitan energi listrik dari 
panel surya rata-rata perhari dalam kondisi cahaya matahari cerah yaitu: $960 \mathrm{watt} / 2 \mathrm{jam}$, atau $480 \mathrm{watt} / 4 \mathrm{jam}$, atau $160 \mathrm{watt} / 12 \mathrm{jam}$ atau $80 \mathrm{watt} / 24 \mathrm{jam}$ pemakaian. PLTS dapat digunakan untuk menyalakan pompa air dengan daya 60 watt selama 24 jam/hari untuk keperluan 10 unit kolam lele biofloc, dan menyaakan lampu penerangan selama 12 jam perhari. Kolam bioffloc yang dihibahkan kepada mitra sebanyak 4 unit kolam berdiameter @ 2 meter, dengan kapasitas 3.000 ekor lele tiap kolam, dilengkapi 12.000 bibit lele ukuran 5-7 cm, dan pakan untuk $1 \mathrm{x}$ panen. Proses kegiatan pengabdian masyarakat sebagaimana Gambar 4-9.

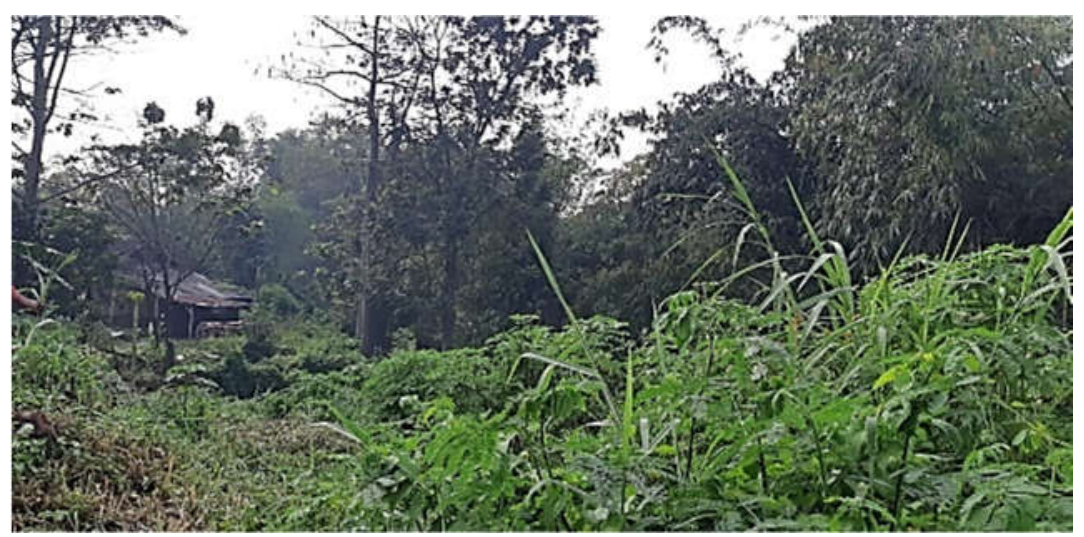

Gambar 4. Kondisi Lahan Kosong Yang Tidak Produktif

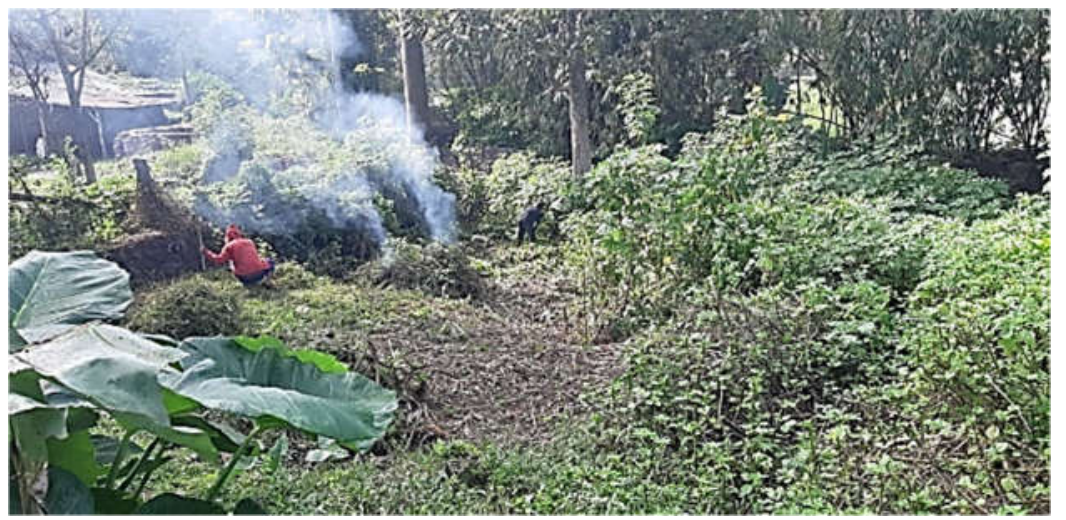

Gambar 5. Pembersihan Lahan Kosong Tidak Produktif Untuk Tempat Kolam

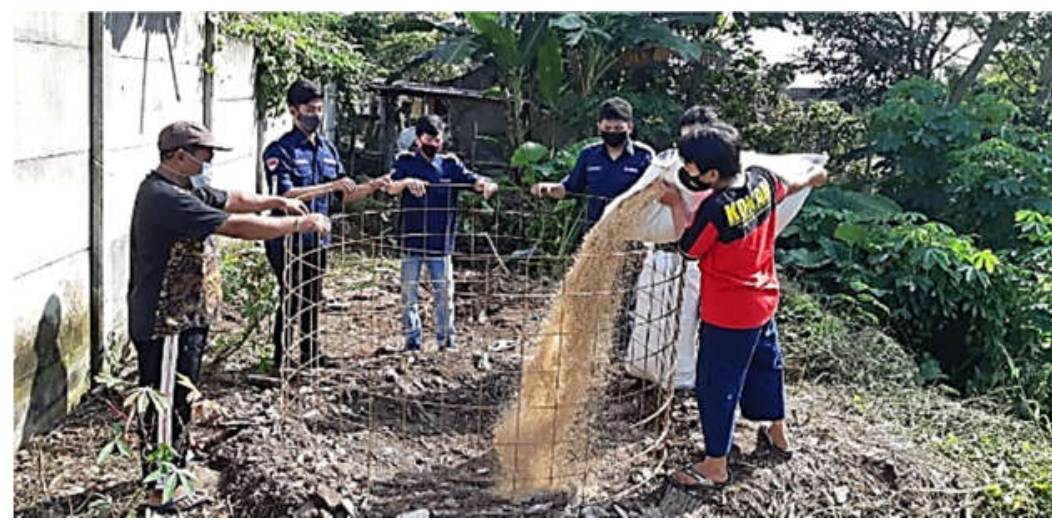

Gambar 6. Pembuatan Kolam 


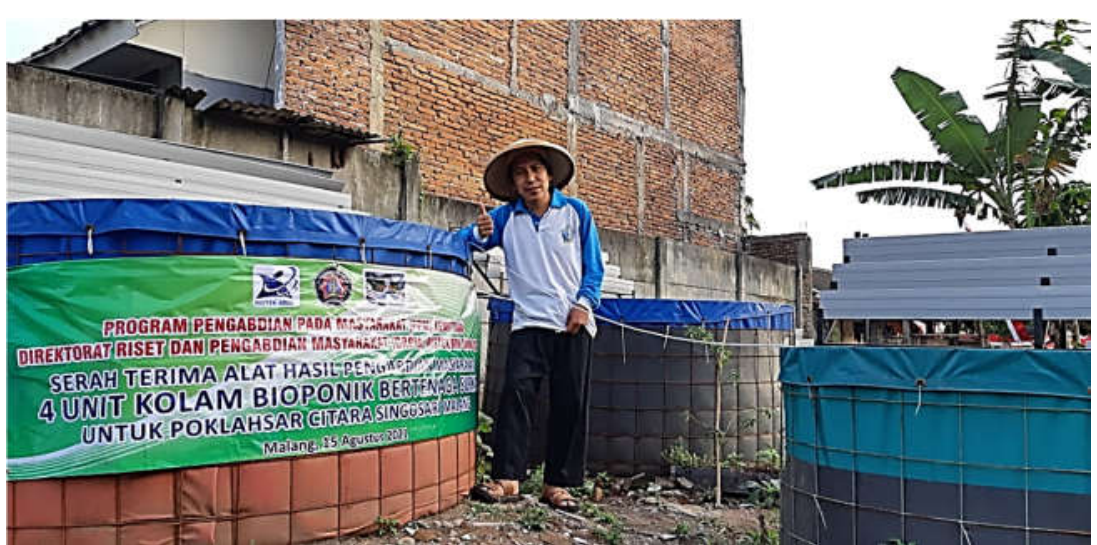

Gambar 7. Ketua Poklahsar Citara di Lokasi Kolam Biofloc Bertenaga Surya Hasil Kegiatan PPM

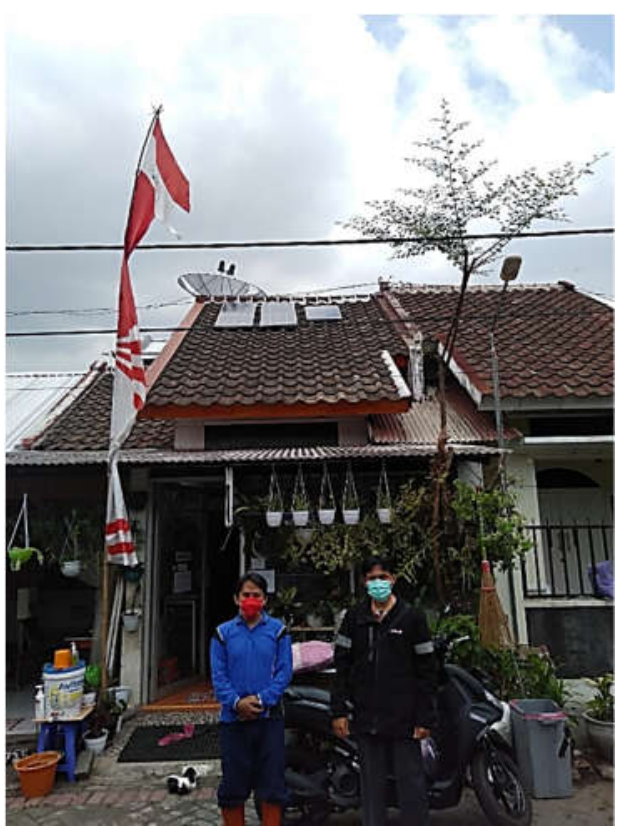

Gambar 8. Lima Unit Solar Panel PLTS Yang Dihibahkan yang Dipasang di Atas Genteng

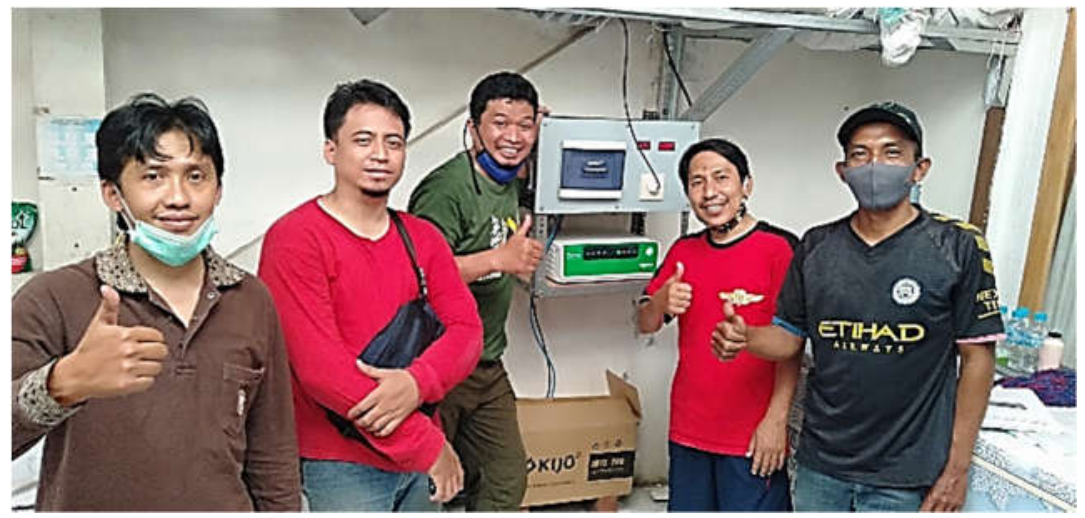

Gambar 9. Alat Controller PLTS yang Dihibahkan 
Gambar 4-9 menunjukkan bahwa tahapan utama proses kegiatan pengabdian masyarakat telah berjalan dengan baik, mulai dari pembersihan lahan, pembuatan kolam biofloc, dan pemasangan panel surya penggerak pompa kolam biofloc. Adapaun analisis usaha budidaya ikan lele pada kolam biofloc Poklahsar Citara sebelum dan sesudah kegiatan pengabdian masyarakat sebagaimana Tabel 1-3.

Tabel 1. Rincian Kapasitas Produksi Budidaya Lele Sebelum Kegiatan PPM

\begin{tabular}{|c|c|c|c|}
\hline No & Keterangan & Jumlah & Satuan \\
\hline 1 & Jumlah kolam & 4 & unit \\
\hline 2 & Jumlah kolam & 1,5 & $\mathrm{~m}^{2}$ \\
\hline 3 & $\begin{array}{l}\text { Kapasitas ikan per unit kolam (mulai } \\
\text { dari size } 5-7 \mathrm{~cm} \text { ) }\end{array}$ & 1.500 & ekor \\
\hline 4 & Kapasitas ikan 4 unit kolam, $1.500 \times 4$ & 6.000 & ekor \\
\hline 5 & $\begin{array}{l}\text { SR (Survival Rate) atau (angka hidup } \\
\text { sampai panen) }\end{array}$ & 80 & $\%$ \\
\hline 6 & Nilai SR $=80 \% \times 6.000$ & 4.800 & ekor \\
\hline 7 & Masa panen & 3 & bulan \\
\hline 8 & $\begin{array}{l}\text { Ukuran ikan saat panen (size) } 1 \mathrm{~kg} \text { size } \\
12 \text {, artinya } 1 \mathrm{~kg} \text { berisi } 12 \text { ekor }\end{array}$ & 12 & ekor \\
\hline 9 & $\begin{array}{l}\text { Jumlah/berat ikan saat panen }=4.800 / \\
12\end{array}$ & 400 & $\mathrm{~kg}$ \\
\hline 10 & $\begin{array}{l}\text { Harga ikan lele per kg } \\
\text { - harga tengkulak } \\
\text { - harga pembeli langsung }\end{array}$ & $\begin{array}{c}16.000 \\
20.000-22.000\end{array}$ & $\begin{array}{l}\text { Rupiah } \\
\text { Rupiah }\end{array}$ \\
\hline 11 & $\begin{array}{l}\text { Omzet panen (per } 3 \text { bulan) } 400 \mathrm{~kg} \times \mathrm{Rp} \\
16.000\end{array}$ & 6.400 .000 & Rupiah \\
\hline 12 & $\begin{array}{l}\text { Omzet panen per tahun } 400 \mathrm{~kg} \times \mathrm{Rp} \\
16.000 \times 4\end{array}$ & 25.600 .000 & Rupiah \\
\hline
\end{tabular}

Tabel 2. Kapasitas Produksi Budidaya Lele Sebelum dan Sesudah PPM

\begin{tabular}{|c|c|c|c|}
\hline No & Keterangan & Sebelum kegiatan PPM & Setelah kegiatan PPM \\
\hline 1 & Jumlah kolam & 4 unit & $\begin{array}{l}10 \text { unit (4 unit hibah, } 2 \\
\text { unit swadaya) }\end{array}$ \\
\hline 2 & Diameter kolam & $1,5 \mathrm{~m}^{2}$ & $2 \mathrm{~m}^{2}$ \\
\hline 3 & Kapasitas ikan maksimum & $1.500 \times 4=6.000$ ekor & $\begin{array}{l}1.500 \times 4=6.000 \text { ekor } \\
3.000 \times 6=18.000 \text { ekor } \\
\text { Total }=24.000 \text { ekor }\end{array}$ \\
\hline \multirow[t]{3}{*}{4} & Omzet & & \\
\hline & - 1 x panen (3 bulan) & $\begin{array}{l}(80 \% \quad \mathrm{x} \quad 6000) / 12 \quad \mathrm{x} \\
16.000 \\
=\text { Rp. } 6.400 .000\end{array}$ & $\begin{array}{l}(80 \% \times 24000) / 12 \times \\
16.000 \\
=R p 25.600 .000\end{array}$ \\
\hline & - per tahun (4 x panen) & $\begin{array}{l}\text { Rp. } 6.400 .000 \times 4 \\
=25.600 .000\end{array}$ & $\begin{array}{l}\text { Rp 25.600.000 x } 4 \\
=102.400 .000\end{array}$ \\
\hline
\end{tabular}

Jumlah kolam ikan lele biofloc yang dimiliki Poklahasar Citara sebanyak 4 unit kolam@ diameter 1,5 $\mathrm{m}^{2}$. Masing-masing kolam bisa diisi benih lele ukuran panjang 5-7 cm sebanyak 1.500 ekor (maksimum), sehingga kapasitas kolam maksimum 6.000 ekor. Waktu yang dibutuhkan untuk sekali panen rata-rata 3 bulan dengan Survival Rate (SR): $80 \%$, artinya mulai dari pembenihan hingga panen, angka hidup ikan adalah $80 \%$, sehingga saat panen diperoleh hasil rata-rata $80 \%$ x 6.000 ekor $=4.800$ ekor. Ukuran ikan saat panen (size) yaitu $1 \mathrm{~kg}$ size 12, artinya pada saat panen untuk $1 \mathrm{~kg}$ berat ikan berisi 12 ekor, 
sehingga jumlah berat ikan yang diperoleh saat panen yaitu $4.800 / 12=400 \mathrm{~kg}$. Harga terendah ikan lele (harga pengepul) per $\mathrm{kg}$ adalah $\mathrm{Rp}$. 16.000, sehingga saat panen diperoleh omzet $400 \mathrm{~kg}$ x Rp. $16.000=\mathrm{Rp} 6.400 .000$ per 3 bulan. Omzet setiap panen Rp. 6.400 .000 ,- Perhitungan biaya produksi dengan biaya pakan ikan lele menggunakan istilah Food Convertion Ratio (FCR), dimana FCR merupakan perbandingan antara total pakan dengan total produksi. Harga pakan per kg adalah Rp. 10.500,-, sehingga biaya pakan per $1 \mathrm{~kg}$ ikan adalah $1,2 \mathrm{~kg}$ pakan x Rp. $10.500=$ Rp. 12.600,-. Harga ikan lele per kg saat panen adalah Rp 16.000,-, sehingga keuntungan produksi per kg ikan diperoleh Rp 16.000 - Rp. $12.600=$ Rp. 3.400,-. Untuk sekali panen per 3 bulan diperoleh hasil ikan $400 \mathrm{~kg}$, sehingga keuntungan produksi per panen adalah $400 \mathrm{~kg}$ x Rp. $3.400=\mathrm{Rp} 1.360 .000,-$. padahal biaya listrik Rp 1.200.000, sehingga dapat dikatakan usahanya masih impas, belum ada keuntungan.

Berdasarkan data pada Tabel 2 dapat disimpulkan bahwa besarnya peningkatan kapasitas produksi setelah kegiatan PPM ini adalah sebesar 4 kali dari sebelumnya. Berdasarkan data pada Tabel 3 dapat disimpulkan bahwa besarnya peningkatan kapasitas produksi setelah tidak adanya biaya listrik karena kebutuhan listrik disuplai oleh panel surya sebesar 5 kali dari sebelumnya.Artinya bahwa pemasangan panel surya sebagai penggerak pompa kolam biofloc mampu menambah peningkatan kapasitas produksi budidaya lele sebesar 1 kali, dari semula 4 kali menjadi $5 x$ kali dibanding sebelum kegiatan pengabdian kepada masyarakat ini.

Tabel 3. Biaya Listrik Sebelum dan Sesudah Kegiatan PPM

\begin{tabular}{|c|c|c|c|}
\hline No & Keterangan & Sebelum kegiatan PPM & Setelah kegiatan PPM \\
\hline 1 & $\begin{array}{l}\text { Biaya listrik } 4 \text { kolam per } \\
\text { bulan }\end{array}$ & $4 \times 100.000=400.000$ & 0 \\
\hline 2 & $\begin{array}{l}\text { Biaya listrik } 4 \text { kolam per } \\
\text { panen ( } 3 \text { bulan) }\end{array}$ & $3 \times 400.000=1.200 .000$ & 0 \\
\hline 3 & $\begin{array}{l}\text { Biaya listrik } 4 \text { kolam per } \\
\text { tahun }(4 \times \text { panen })\end{array}$ & $\begin{array}{l}4 \times 1.200 .000= \\
4.800 .000\end{array}$ & 0 \\
\hline \multirow[t]{3}{*}{4} & $\begin{array}{l}\text { Omzet dikurangi biaya } \\
\text { listrik }\end{array}$ & & \\
\hline & $-1 \mathrm{x}$ panen $(3$ bulan $)$ & $\begin{array}{l}6.400 .000-1.200 .000= \\
5.200 .000\end{array}$ & $\begin{array}{l}25.600 .000-0= \\
25.600 .000\end{array}$ \\
\hline & - per tahun (4 x panen) & $\begin{array}{l}25.600 .000-4.800 .000 \\
=20.800 .000\end{array}$ & $\begin{array}{l}102.400 .000-0= \\
102.400 .000\end{array}$ \\
\hline 5 & \multicolumn{3}{|c|}{ Besarnya peningkatan sesudah kegiatan PPM $=5 \mathrm{x}$} \\
\hline 6 & \multicolumn{3}{|c|}{ Pengurangan biaya listrik menambah peningkatan sebanyak 1x } \\
\hline
\end{tabular}

\section{DAMPAK DAN MANFAAT}

Dampak ekonomi yang ditimbulkan setelah kegiatan PPM ini bagi Poklahsar Citara adalah tercapainya peningkatan kapasitas produksi budidaya ikan lele biofloc dan berkurangnya biaya listrik, sehingga terjadi peningkatan pendapatan dan ketahanan pangan. Peningkatan kapasitas produksi setelah kegiatan PPM ini adalah sebesar 4 kali dari sebelumnya, sedangkan biaya listrik turun $100 \%$, yang semula Rp. 1.2000.000,- untuk 4 kolam menjadi Rp. 0 untuk 10 kolam. Penurunan biaya listrik mampu meningkatkan perhitungan kapasitas produksi dari 4 kali menjadi 5 kali.

Sedangkan dampak sosial yang ditimbulkan setelah kegiatan PPM ini bagi Poklahsar Citara dan warga sekitar adalah telah terjadinya perubahan sosial dan lingkungan, yaitu:

1. Masyarakat sekitar dibawah koordinasi Poklahsar Citara mau dan bersemangat bergabung mengembangkan usaha budidaya ikan lele biofloc. Sebanyak 23 warga sekitar gotong royong membangun 2 kolam lele secara swadaya akibat adanya 
kegiatan PPM ini. Partisipsi warga sebagaimana Gambar 10.

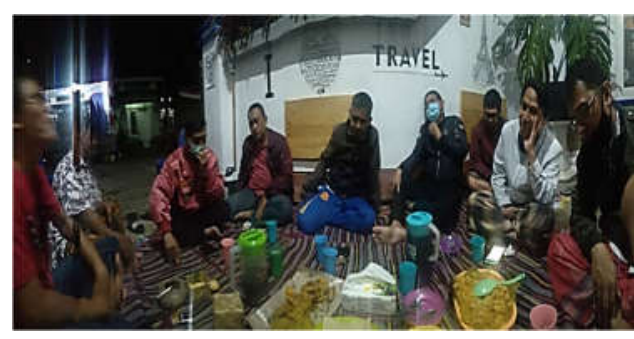

a

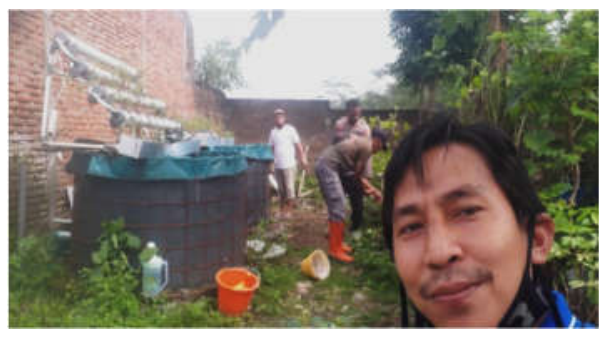

b

Gambar 10. Partisipasi warga dalam kegiatan PPM

a) koordinasi pengembangan budidaya lele biofloc, b) kerjabakti penyiapan kolam

2. Terjadi pemberdayaan lahan kosong yang tidak produktif sebagaimana Gambar 11 menjadi lahan produktif. Lahan kosong di pinggir sungai seluas $\pm 2000 \mathrm{~m} 2$ yang semula tidak produktif, jarang dijamah masyarakat, sekarang menjadi lahan yang produktif dan potensial untuk dikembangkan lebih lanjut. saat ini sudah ada lebih dari 10 unit kolam di lahan tersebut dan beberapa petak tanah yang siap dijadikan lahan perkebunan/pertanian.

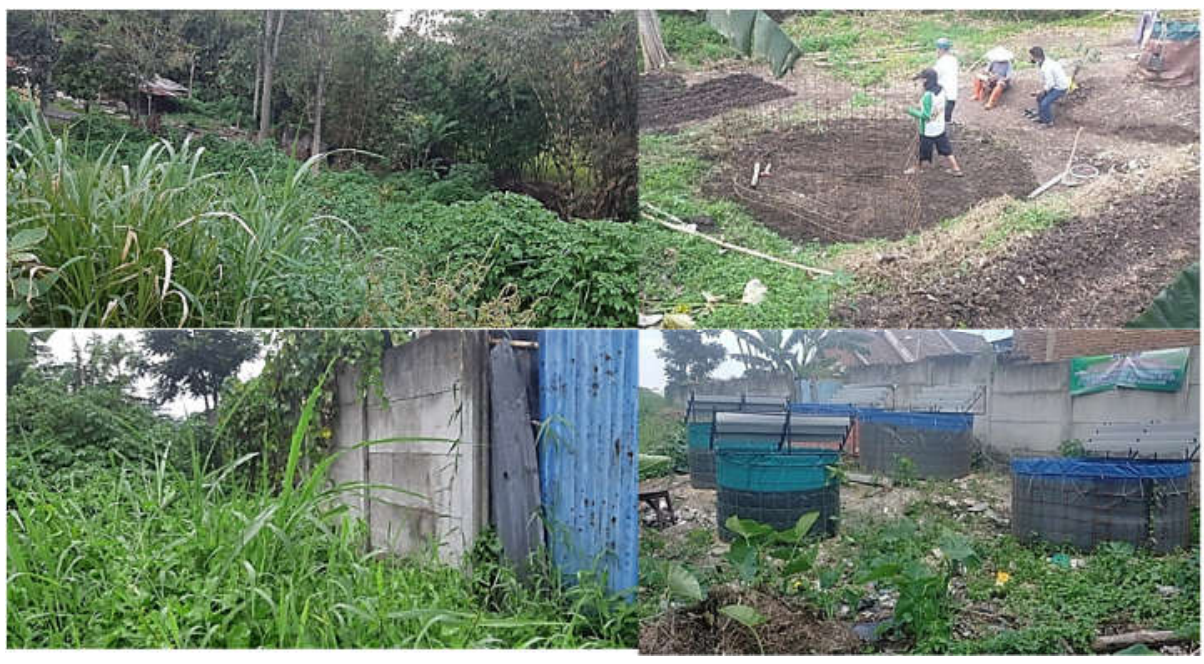

a

$\mathrm{b}$

Gambar 1. Pemberdayaan Lahan Kosong

a) lahan kosong tidak produktif, b) lahan menjadi produktif

3. Poklahsar Citara menjadi satu-satunya UKM di kabupaten Malang yang telah menggunakan teknologi panel surya. Dengan teknologi ini, image dan citra positif UKM Citara meningkat di mata masyarakat.

\section{KESIMPULAN}

Kegiatan PPM ini menghasilkan 2 karya utama, yaitu: 1) empat unit kolam biofloc, masing-masing berdiameter 2 meter dengan kapasitas 3.000 ekor ikan/kolam, dan 2) satu set instalasi panel surya berkapasitas $500 \mathrm{WP}$ yang mampu menyalakan pompa air selama $24 \mathrm{jam} / \mathrm{hari}$ untuk 10 unit kolam. Dengan kegiatan PPM ini terjadi penambahan unit kolam di Poklahsar Citara, yang semula hanya 4 unit menjadi 10 unit (4 unit hibah PPM dan 2 
unit swadaya masyarakat) sehingga terjadi peningkatan kapasitas produksi dan proyeksi peningkatan omzet UKM sebesar 4x. Setelah kegiatan PPM ini juga terjadi penurunan biaya listrik, yang semula untuk sekali panen 4 kolam sebesar Rp. 1.200.000, menjadi Rp. 0 untuk 10 unit kolam.

\section{UCAPAN TERIMA KASIH}

Ucapan terimakasih disampaikan kepada DRPM Ristek BRIN yang telah mendanai kegiatan ini melalui UPT P2M Polinema, Poklahsar Citara sebagai mitra kegiatan dan anggota tim pelaksana PPM baik dari unsur dosen maupun mahasiswa.

\section{REFERENSI}

Anonimous. (2020). Daftar Tarif Listrik Terbaru 2020 Kementerian ESDM [Oktober Desember]. from https://lifepal.co.id/media/daftar-tarif-listrik-terbaru/

Bahtiar, R. A., \& Saragih, J. P. (2020). Dampak Covid-19 terhadap Perlambatan Ekonomi Sektor UMKM. Jurnal Bidang Ekonomi Dan Kebijakan Publik, 7(6), 19-24.

Faridah, F., Diana, S., \& Yuniati, Y. (2019). Budidaya Ikan Lele Dengan Metode Biofloc Pada Peternak Ikan Lele Konvesional. CARADDE: Jurnal Pengabdian Kepada Masyarakat, 1(2), 224-227.

Handayani, D., Hadi, D. R., Isbaniah, F., Burhan, E., \& Agustin, H. (2020). Penyakit Virus Corona 2019. Jurnal Respirologi Indonesia, 40(2), 119-129.

Kamalia, S., Dewanti, P., \& Soedradjad, R. (2017). Teknologi Hidroponik Sistem Sumbu Pada Produksi Selada Lollo Rossa (Lactuca sativa L.) Dengan Penambahan CaCl2 Sebagai Nutrisi Hidroponik. Jurnal Agroteknologi, 11(01), 96-104.

Manggala P Putra, Y. (2015). Budidaya Lele Bersistem Biofloc Hasilnya 10 Kali Lipat. from https://republika.co.id/berita/nasional/daerah/15/11/23/ny9rm4284-budidayalele-bersistem-biofloc-hasilnya-10-kali-lipat.

Murniaseh, E. (2020). Teknik Cara Menanam Hidroponik \& Jenis Tanaman yang Cocok. from https://tirto.id/teknik-cara-menanam-hidroponik-jenis-tanaman-yang-cocokfXTf.

Rakhman, A. (2015). Pertumbuhan tanaman Sawi Menggunakan Sistem Hidroponik Dan Akuaponik: Fakultas Pertanian.

Susilo, A., Rumende, C. M., Pitoyo, C. W., Santoso, W. D., Yulianti, M., Herikurniawan, H., Nelwan, E. J. (2020). Coronavirus Disease 2019: Tinjauan Literatur Terkini. Jurnal Penyakit Dalam Indonesia, 7(1), 45-67.

Utomo, W. S. (2020). Company Profile Poklahsar Citara, Banjararum, Singosari, Malang. 
Filename: 9. JSolid_Vol4No2_Oktober 2021_Nurhadi_16-25_Fix Cetak.docx

Directory: $\quad$ C: $\quad$ U Users $\backslash h p \backslash$ Documents

Template: $\quad$ C: $\backslash$ Users $\backslash h p \backslash A p p D a t a \backslash$ Roaming $\backslash$ Microsoft $\backslash$ Templates $\backslash$ Normal.dotm

Title:

Subject:

Author:

Keywords:

Tatang

Comments:

Creation Date: $\quad$ 09-Sep-21 12:42:00 PM

Change Number: 6

Last Saved On: $\quad$ 16-Sep-21 9:42:00 PM

Last Saved By: $\quad$ hp

Total Editing Time: 14 Minutes

Last Printed On: $\quad$ 16-Sep-21 9:42:00 PM

As of Last Complete Printing

Number of Pages: 10

Number of Words: $\quad 4,636$ (approx.)

Number of Characters: 26,428 (approx.) 